\title{
Pengenalan Label dan Hak Kekayaan Intelektual Kepada Ibu-Ibu Anggota Koperasi di Pamulang Tangerang Selatan
}

\author{
Siswi Wulandari ${ }^{1}$, Rully Noor Oktaviana ${ }^{2}$ \\ ${ }^{1,2}$ Universitas Indraprasta PGRI \\ email : siswiwulandari89@gmail.com ${ }^{1}$, ully.unpad@gmail.com²
}

\begin{abstract}
This activity aims to empower mothers by providing education on labeling and intellectual property rights, especially brands, for women members of the Syariah Mandiri Sejahtera Syariah cooperative in Pinus Barat I Street RT 001 RW 024 Pamulang Barat, South Tangerang. The target of this project plan is one of the tridharma university namely community service. The method used by the lecture team of Indraprasta PGRI University in this activity began with giving socialization on labels and intellectual property rights, counseling on product development by making labels, then proceed with providing information in the registration of the brand. The product to be produced is in the form of a trademark registration guidebook that serves to facilitate the members of the Cooperative in registering trademarks with the Ministry of Law and Human Rights. Through this empowerment it is hoped that it can change the mindset of mothers that product and business development can be done by making attractive labels and also by ownership of brand rights to the products they produce.
\end{abstract}

Keywords: label, intellectual property rights, trademark.

\begin{abstract}
Abstrak
Kegiatan pengabdian masyarakat ini bertujuan untuk memberdayakan ibu-ibu dengan memberikan edukasi mengenai label dan hak kekayaan intelektual terutama merek bagi ibuibu anggota koperasi Syariah Citra Mandiri Sejahtera di Jln. Pinus Barat I RT 001 RW 024 Pamulang Barat, Tangerang Selatan. Target rencana proyek ini salah satu dari tridharma perguruan tinggi yaitu pengabdian kepada masyarakat. Metode yang digunakan oleh tim dosen Universitas Indraprasta PGRI dalam kegiatan ini diawali dengan pemberian ceramah mengenai mengenai label dan hak kekayaan intelektual, penyuluhan pengembangan produk dengan membuat label, kemudian dilanjutkan dengan memberikan informasi dalam pendaftaran merek. Adapun produk yang akan dihasilkan berupa buku panduan pendaftaran merek yang berfungsi untuk memudahkan ibu-ibu anggota koperasi dalam melakukan pendaftaran merek ke Kementerian Hukum dan HAM. Melalui pemberdayaan ini diharapkan dapat merubah pola pikir ibu-ibu bahwa pengembangan produk dan usaha, dapat dilakukan dengan membuat label yang menarik dan juga dengan kepemilikan hak merek atas produk yang mereka hasilkan.
\end{abstract}

Kata Kunci: label, hak kekayaan intelektual, merek

Artikel diterima : 21 Juli 2020 direvisi : 7 September 2020 disetujui : 1 Desember 2020 


\section{Pendahuluan}

Label merupakan suatu bagian dari sebuah produk yang membawa informasi verbal tentang produk atau penjualnya. Menurut Tjiptono (dalam Yusuf, 2017) label merupakan bagian dari suatu produk yang menyampaikan informasi mengenai produk dan penjualan. Sebuah label biasa merupakan bagian dari kemasan, atau bisa pula merupakan etiket (tanda pengenal) yang dicantelkan pada produk. Sedangkan Kotler (dalam Fajri, 2015) menyatakan bahwa label adalah tampilan sederhana pada produk atau gambar yang dirancang dengan rumit yang merupakan satu kesatuan dengan kemasan. Label bisa hanya mencantumkan merek atau informasi.

Hak Kekayaan Intelektual adalah istilah yang dipergunakan untuk merujuk kepada seperangkat hak eksklusif yang masing-masing diberikan kepada seseorang yang telah menghasilkan karya dari olah pikirnya, yang memiliki wujud, sifat atau memenuhi kriteria tertentu berdasarkan peraturan perundang-undangan yang berlaku. (http://www.hki.co.id/hki.html) Istilah Hak kekayaan Intelektual biasa pula disingkat dengan HKI. Baik "Hak Kekayaan Intelektual" maupun "HKI" sebagai bentuk penyingkatannya merupakan padanan baku dan resmi dalam Bahasa Indonesia untuk istilah "Intellectual Property Rights" atau "IPR", sebagaimana dipergunakan dalam beragam aturan perundang-undangan serta penamaan untuk unit teknis negara yang diserahi tanggungjawab untuk menyelenggarakan sistem pemberian dan pengelolaan HKI, yaitu Direktorat Jenderal Hak Kekayaan Intelektual.

Hak Kekayaan Intelektual atau HKI tidak merujuk pada salah satu jenis hak eksklusif semata, melainkan sebuah "payung", umbrella term, untuk menaungi beragam jenis hak eksklusif yang masingmasing memiliki karakteristik, ruang lingkup dan sejarah perkembangannya sendiri-sendiri. (http://www.hki.co.id/hki.html)
Salah satu jenis HKI yang erat kaitannya dengan dunia bisnis adalah hak merek. Merek merupakan aset yang sangat penting bagi bisnis sehingga diperlukan perlindungan khusus bagi merek yang di miliki. Sebenarnya merek, brand, dan branding adalah satu paket. Merek dan brand mengacu kepada satu term yang sama. Sedangkan branding lebih kepada upaya membangun merek yang bisa dilihat dari tingkat brand awareness masyarakat terhadap merek produk atau jasa tersebut. Branding kerap dinilai sebagai salah satu strategi penting untuk mengembangkan sebuah bisnis. Melalui branding ini, merek dari produk ataupun jasa menjadi lebih mudah dikenali oleh masyarakat. Hal ini akan membantu meningkatkan penjualan dari produk maupun jasa.

Di Undang-Undang Nomor 20 Tahun 2016 tentang Merek disebutkan merek adalah tanda yang berupa gambar, nama, kata, huruf-huruf, angka-angka, susunan warna, atau kombinasi dari unsurunsur tersebut yang memiliki daya pembeda dan digunakan dalam kegiatan perdagangan barang atau jasa. Negara memang melindungi hak ekonomi dari tiap pemegang hak atas merek. Hak ekonomi ini bisa terwujud dalam bentuk royalti. Selain motif ekonomi, apa lagi urgensi untuk mendaftarkan merek bagi UMKM? (https://www.easybiz.id )

1. Merek merupakan ciri khas (pembeda) dari usaha.

2. Kompetisi dalam bisnis adalah hal yang tidak terelakkan, sehingga bukan tidak mungkin saat bisnis berkembang, penirunya akan banyak. Dengan situasi seperti ini, ada potensi merek yang didaftarkan lebih dahulu oleh orang lain yang meniru makin besar.

3. Merek merupakan aset yang tidak berwujud dan merupakan hak eksklusif yang diberikan negara pada pemegang haknya. Saat ini pemerintah sedang mengupayakan agar kekayaan intelektual bisa dijadikan agunan. Jadi, sebagai pemegang merek terdaftar bisa 
mengagunkannya untuk mendapatkan pinjaman dari bank, misalnya;

4. Pemilik merek yang sudah terdaftar, bisa meminta royalti pada orang yang menggunakan merek tersebut; dan yakinlah bahwa bisnis tersebut akan semakin besar, sehingga melindungi merek dengan mendaftarkannya secara dini adalah langkah kehati-hatian dalam bisnis.

Dari uraian di atas dapat disimpulkan bahwa label dan merek merupakan salah satu upaya dalam memajukan bisnis terutama bagi UMKM. Kegiatan pengabdian kepada masyarakat ini bertujuan untuk memberikan pengetahuan dasar mengenai label dan hak kekayaan intelektual, terutama merek. Tujuan khusus dari pengabdian kepada masyarakat ini adalah:

a. Memberikan edukasi mengenai urgensi label dan merek;

b. Memberikan pengetahuan mengenai cara mendaftarkan merek.

Pada pengenalan label dan hak kekayaan intelektual terutama merek dalam hal ini menggandeng satu mitra, yaitu Koperasi Syariah Citra Mandiri Sejahtera yang berolakasi di Pamulang, Tangerang Selatan. Mitra Koperasi ini beranggotakan lebih kurang 50 orang anggota yang terdiri dari wanita, baik yang berlatar belakang wanita pekerja maupun ibu rumah tangga. Dimana para anggota ini memiliki suatu usaha berskala UMKM di berbagai bidang.

Mereka ikut bergabung dalam koperasi bertujuan agar ada sarana yang menaungi produk-produk yang mereka hasilkan. Pada observasi awal, ditemukan bahwa para pelaku usaha yang menjadi anggota Koperasi Syariah Citra Mandiri Sejahtera tidak satupun memiliki label yang menarik pada produknya. Label yang digunakan terkesan apa adanya dan sangat sederhana. Selain itu juga, hampir seluruhnya belum mengetahui mengenai hak kekayaan intelektual, hak merek, serta cara mendaftarkannya.

Mereka juga mengeluhkan bahwa usaha mereka sulit sekali berkembang dikarenakan kalah dengan produk-produk lain di luar yang sangat menarik dari brand image, brandingnya, kemasannya, labelnya hingga cara pemasarannya. Para Ibu anggota koperasi berharap usaha nya bisa berkembang dan bisa dijual secara meluas. Dengan keadaan ini maka, dibutuhkan pengenalan dan pembelajaran tentang pentingnya memiliki label yang menarik (eye catching) agar dapat menarik minat konsumen dan juga mengenai urgensi merek. Bukan hanya itu, mitra juga diberikan pengenalan terhahadap PIRT, yaitu Sertifikat Produksi Industri Rumah Tangga. Karena produk yang dihasilkan oleh anggota koperasi didominasi oleh produk pangan. Dari mulai snack, minuman sampai frozen food.

Mengingat berbagai permasalahan yang dihadapi oleh anggota koperasi maka dianggap perlu dan penting untuk memberikan pengenalan dan pelatihan mengenai label, PIRT dan juga merek. Kegiatan pengabdian kepada masyarakat ini bertujuan untuk memberikan pengetahuan dasar mengenai label dan hak kekayaan intelektual, terutama merek.

\section{Pelaksanaan dan Metode}

Penyuluhan merupakan upaya yang dilakukan untuk mendorong terjadinya perubahan perilaku pada individu, kelompok ataupun masyarakat, agar mereka tahu, mau dan mampu menyelesaikan permasalahan yang dihadapi (Siti Amanah, 2007). Pendampingan merupakan proses interaksi timbal balik (tidak satu arah) antara individu/kelompok/komunitas yang mendampingi dan individu/ kelompok/ komunitas yang didampingi yang bertujuan memotivasi dan mengorganisir individu/kelompok/komunitas dalam mengembangkan sumber daya dan potensi orang yang didampingi dan tidak menimbulkan ketergantungan terhadap orang yang mendampingi (mendorong kemandirian) (Baiq, 2019). Pendampingan dapat dilakukan dengan formal maupun nonformal. Individu maupun komunitas. 
Dengan konsep penyuluhan dan pendampingan maka sebagai metode pendukung adalah melakukan bimbingan terstruktur yaitu upaya memberikan pengarahan dalam mengatasi permasalahan yang dilakukan secara terus menerus dan sistematis dalam mendampingi (memfasilitasi) individu, kelompok sehingga mereka dapat mengatasi permasalahan tersebut dan mencapai perubahan hidup ke arah yang lebih baik.

Seluruh kegiatan penyuluhan dilakukan oleh tim dosen. Sedangkan untuk kelancaran kegiatan, yakni segala sesuatu yang dibutuhkan dalam kegiatan ini, diantaranya: tempat penyuluhan, meja, dan kursi akan disediakan oleh pihak Mitra. Dalam memberikan pengetahuan teoritis dan deskripsi praktis atas tema yang kami laksanakan, maka tim kami menggunakan metode penyuluhan, pendampingan serta bimbingan terstruktur. Untuk melakukan metode tersebut, kami melakukan presentasi sederhana melalu slide power point pada materi-materi yang kami sampaikan.

Selain itu untuk mencapai tujuan yang diharapkan, selama proses kegiatan berlangsung peserta diberikan kesempatan untuk berkomunikasi langsung dengan tim pengabdian masyarakat, baik dalam bentuk telepon, email, face to face kepada pendamping yang selalu berupaya untuk berada ditengah-tengah mereka.

\section{Hasil dan Pembahasan}

Label adalah salah satu bagian dari produk berupa keterangan baik gambar maupun kata-kata yang berfungsi sebagai sumber informasi produk dan penjual. Label umumnya berisi informasi berupa nama atau merek produk, bahan baku, bahan tambahan komposisi, informasi gizi, tanggal kedaluwarsa, isi produk dan keterangan legalitas.

Menurut Kotler (dalam Fajri 2015), fungsi label adalah:

1. Label mingidentifikasi produk atau merek

2. Label menentukan kelas produk
3. Label menggambarkan beberapa hal mengenai produk (siapa pembuatnya, dimana dibuat, kapan dibuat, apa isinya, bagaimana menggunakannya, dan bagaimana menggunakan secara aman)

4. Label mempromosikan produk lewat aneka gambar yang menarik.

Menurut Fajri (2015) bagi konsumen, label mempunyai peranan yang sangat penting, setidaknya ada tiga hal pokok yang mendasarinya yaitu:

1. Informasi yang dibutuhkan sebagai pertimbangan untuk membeli atau tidak produk tertentu;

2. Dengan pengetahuan tersebut, konsumen dapat menentukan, memilih satu produk atas produk sejenis lainnya;

3. Dengan informasi yang benar dan lengkap, konsumen juga dapat terhindar dari kemungkinan gangguan keamanan dan keselamatan konsumsinya, bila produksi bersangkutan tidak cocok untuk dirinya atau mengandung suatu zat yang membahayakan.

Dalam memilih sebuah produk selain label adalah adanya ijin dari Dinas Kesehatan P-IRT (Sertifikat Produksi Industri Rumah Tangga). Berdasarkan Undang-undang RI No 18 Tahun 2012 tentang Pangan mengatur bahwa tujuan pengaturan, pembinaan dan pengawasan pangan adalah untuk tersedianya pangan yang memenuhi persyaratan keamanan, mutu dan gizi bagi kepentingan kesehatan manusia. Oleh karena itu, SP-IRT (Sertifikat Produksi Industri Rumah Tangga) dan izin Dinas Kesehatan sangat dibutuhkan untuk meningkatkan kualitas Industri Rumah Tangga pangan, sehingga mampu meletakkan Industri Rumah Tangga pangan dalam posisi strategis dan sehat. Salah satu polemik yang di dalam masyarakat adalah banyak produk industri rumah tangga (UMKM) yang tidak memiliki izin dari dinas kesehatan.

Dalam penelitian Hermanu (2016) menjelaskan kebanyakan dari pelaku usaha industri rumah tangga atau kecil sangat sadar akan hal itu, akan tetapi pemikiran 
karena usaha sudah berjalan sejak lama banyak yang melakukan tindakan kecurangan. Hal ini yang biasanya banyak ditemukan produk pangan yang tidak memenuhi standar mutu dan keamanan. Rendahnya pengetahuan, tanggung jawab dan kepedulian terhadap konsumen menjadi penyebab utamanya. Setiap produk yang sudah memiliki izin dari Dinas Kesehatan dan P-IRT sudah dipastikan sesuai dengan standar keamanan, mutu, dan kualitas produk. Pada dasarnya setiap produk pangan paling penting memiliki izin edar sesuai dengan keputusan dari Kepala Badan Pengawas Obat dan Makanan (BPOM) dan Peraturan Daerah setempat, walaupun itu bentuknya adalah industri rumah tangga atau UMKM tapi memiliki peraturan yang sama. (Rifqy Suprapto, 2020).

Dari laman http://www.hki.co.id/ Direktorat Jenderal HKI menjelaskan bahwa pemakaian merek berfungsi sebagai:

1. tanda pengenal untuk membedakan hasil produksi yang dihasilkan seseorang atau beberapa orang secara bersama-sama atau badan hukum dengan produksi orang lain atau badan hukum lainnya;

2. sebagian alat promosi, sehingga mempromosikan hasil produksinya cukup dengan menyebut mereknya;

3. sebagai jaminan atas mutu barangnya;

4. menunjukkan asal barang/jasa dihasilkan

Usaha Kecil Mikro Menengah (selanjutnya disebut UMKM) merupakan industri yang berkembang dengan sangat cepat dan besar di Indonesia. Industri UMKM menjadi salah satu pilar perekonomian yang menggerakkan roda perekonomian di Indonesia. Sektor bisnis tidak pernah dapat luput dari Kekayaan Intelektual. Setiap usaha yang dilakukan pasti memiliki kekayaan intelektual yang terdapat di dalamnya. Sama halnya dengan UMKM, meskipun skala bisnis yang dijalankan di dalam UMKM bukanlah suatu skala yang besar tetapi pada umumnya seluruh UMKM memiliki suatu merek.
UMKM sebagai suatu industri berskala kecil masih menganggap bahwa perlindungan kekayaan intelektual bukanlah merupakan hal yang penting. Hal tersebut dibuktikan dengan masih minimnya pendaftaran merek UMKM kepada Ditjen Kekayaan Intelektual.

Dirjen KI mengemukakan bahwa pendaftaran merek berfungsi sebagai alat bukti bagi pemilik yang berhak atas merek yang didaftarkan, sebagai dasar penolakan terhadap merek yang sama keseluruhan atau sama pada pokoknya yang dimohonkan pendaftaran oleh orang lain untuk barang atau jasa sejenisnya, dan juga berfungsi sebagai dasar untuk mencegah orang lain memakai merek yang sama keseluruhan atau sama pada pokoknya dalam peredaran untuk barang atau jasa sejenisnya.

Koperasi Syariah Citra Mandiri Sejahtera merupakan sebuah wadah yang menaungi para ibu-ibu pelaku usaha (UMKM) yang bergerak di berbagai bidang. Ada bidang makanan, fashion ataupun bidang kerajinan. Para anggota koperasi dinaungi dalam koperasi tersebut dengan tujuan agar UMKM ini dapat cepat berkembang dan dapat memperbaiki kondisi perekonomian. Sehingga di anggap perlu diberikan sebuah pencerahan mengenai apa saja upaya yang dapat dilakukan agar produk-produk yang mereka hasilkan dapat dikenal masyarakat dan dapat memperluas area penjualannya.

Hasil evaluasi setelah diadakan kegiatan pemberian informasi berupa penyampaian materi label dan merek pada ibu-ibu anggota Koperasi Syariah Citra Mandiri Sejahtera di Pamulang Tangerang Selatan, ditemukan fakta yaitu masih awamnya atau minimnya pengetahuan para ibu mengenai label dan merek.

Para ibu belum mengetahui apa fungsi label bagi produk yang mereka hasilkan dan jual. Para ibu juga belum mengetahui bagaimana label yang menarik akan mempengaruhi konsumen untuk membeli produk mereka. Serta mereka juga 
tidak mengetahui bagaimana cara membuat label yang menarik perhatian.

Selain itu, hal yang sama berlaku pula terhadap merek. Ibu-ibu tidak mengetahui bahwa merek merupakan satu hal yang penting bagi keberlangsungan usaha mereka dan merupakan prasyarat apabila mereka ingin melebarkan sayap usahanya di area yang lebih luas lagi.

Tim juga menyampaikan mengenai PIRT atau pengurusan izin bagi produk industri rumah tangga. Karena kebanyakan produk yang dihasilkan oleh para anggota koperasi tersebut adalah olahan makanan. Dimana dengan PIRT olahan makanan yang diproduksi terjamin kebersihan dan kesehatannya. Dengan adanya PIRT tersebut sudah barang tentu akan menjadi jaminan perlindungan terhadap konsumen atas keamanan produk makanan yang di jual.

Hal-hal yang disampaikan selain memberikan pencerahan tentang fungsi label dan merek, disampaikan pula mengenai prosedur dan cara pengurusan izin merek serta PIRT tersebut. Kebanyakan di masyarakat tersebar informasi bahwa pengurusan izinnya akan memakan waktu yang sangat panjang, ribet juga mahal. Padahal semua itu merupakan mitos belaka. Pengurusan merek maupun PIRT sudah sangat di permudah oleh pemerintah. di laman www.dgip.go.id telah di cantumkan dengan jelas diagram alur permohonan atas merek. Juga di laman yang sama, para pemohon dapat memeriksa biaya yang harus dikeluarkan pada saat pengurusan pendaftaran merek. Sehingga hal ini mematahkan semua informasi yang tersebar di masyarakat mengenai persepsi mengurus hal-hal di pemerintahan membutuhkan waktu dan ribet.

Setelah penyampaian hal tersebut kepada para ibu anggota koperasi, mereka jadi mengetahui informasi baru mengenai label dan juga merek. Tim membagikan buku panduan permohonan merek serta formulir pendaftaran merek agar memudahkan para ibu terutama ibu-ibu yang kurang memahami penggunaan internet.
Di dalam proses pemberian informasi terbangun proses tanya jawab antara tim dan juga ibu-ibu anggota Koperasi. Ibuibu terlihat bersemangat dan berusaha menggali lebih dalam lagi mengenai informasi tentang label, PIRT dan juga merek. Tim berusaha menjawab semua pertanyaan dengan baik, dengan harapan agar Ibu-ibu menadapatkan pencerahan dan pemahaman yang lebih terkait materi yang disampaikan. Lebih baiknya lagi apabila tujuan utama tim dapat terwujud, yaitu mendorong Ibu-ibu para pelaku UMKM tersebut dapat membuat label yang menarik, mendaftarkan PIRT dan juga mereknya sehingga produknya dapat dipasarkan dengan lebih baik lagi.

Tidak sampai di hari itu saja, tim tetap membuka ruang kepada para ibu untuk bisa menghubungi tim secara pribadi apabila ada hal yang ingin dikonsultasikan atau didiskusikan. Karena baiknya pelaksanaan kegiatan ini bukan hanya saja penyampaian informasi tetapi juga bisa dalam bentuk pendampingan sehingga hasil yang dicapai dari pelaksanaan kegiatan dapat terwujud dengan baik.

Berikut dokumentasi pada saat pelaksanaan kegiatan:

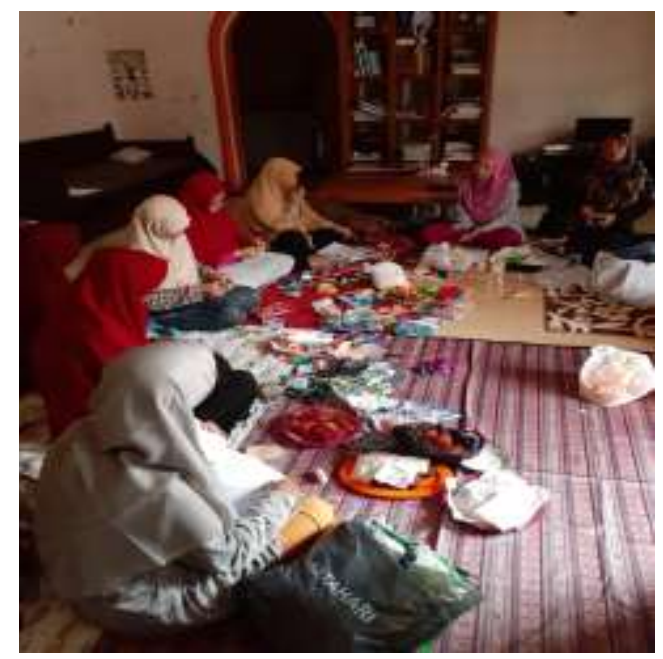

Gambar 1. Saat sesi pemaparan HKI 


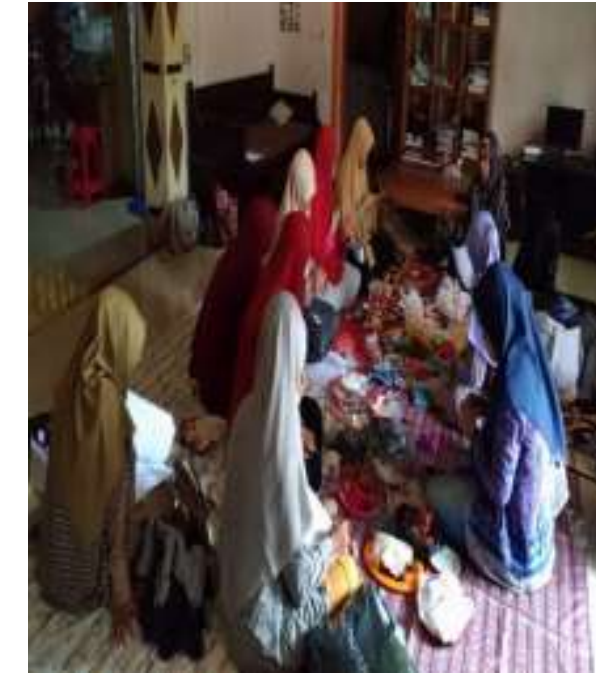

Gambar 2. Saat sesi pemaparan PIRT

\section{Penutup}

\section{Simpulan}

Simpulan dari seluruh rangkaian kegiatan yang dilakukan adalah masih minimnya informasi mengenai label dan juga merek. Baik mengenai fungsinya maupun prosedur pendaftarannya. Sehingga setelah kegiatan ini diharapkan adanya pencerahan kepada peserta yang tidak pham menjadi paham. Selain itu, diharapkan pula para peserta yaitu ibu-ibu anggota koperasi dapat terdorong untuk membuat label yang lebih menarik, mengurus izin PIRT bagi yang memiliki produk makanan serta mendaftarkan mereknya.

\section{Saran}

Saran kedepannya adalah usaha untuk memajukan koperasi tidak boleh berhenti sampai di sini saja. Harus ada tindak lanjut dari kegiatan ini. Sehingga ibu-ibu anggota koperasi benar-benar dapat merealisasikan kepemilikan atas PIRT dan juga hak merek atas produknya. Lebih baik lagi apabila dapat dibuka kesempatan bekerjasama dengan Pemerintah Kota Tangerang Selatan untuk mensosialisasikan hal tersebut kepada koperasi lainnya dan memfasilitasi koperasi agar lebih mudah melakukan pengurusan pendaftaran PIRT dan hak merek. Selain itu, pihak koperasi harus terus menerus memberikan motivasi dan juga dorongan kepada anggotanya agar terus mengembangkan usahanya. Serta dapat membantu dan memfasilitasi anggotanya yang akan mengurus PIRT dan juga merek.

\section{Daftar Pustaka}

Amanah, S. 2007. Makna Penyuluhan dan Tranformasi Perilaku Manusia. Jurnal Penyuluhan. Retrieved from http://journal.ipb.ac.id/index.php/ju pe/article/view/2152

Andriansyah, Y., Arifin, R., \& S, A. R. 2017. Pengaruh Label Halal, Citra Merek Dan Kualitas Produk Terhadap Keputusan Pembelian Teh Racek (Studi Kasus Pada Mahasiswa Fakultas Ekonomi Universitas Islam Malang). e Jurnal Riset Manajemen. Retrieved from

http://riset.unisma.ac.id/index.php/j $\mathrm{rm} /$ article/view/439/473

Betlehn, A., \& Samosir, P. O. (2018). Upaya Perlindungan Hukum Terhadap Merek Industri Umkm Di Indonesia. Jurnal Law and Justice. Retrieved from http://journals.ums.ac.id/index.php/ laj/article/view/6080/4178

Fajri. 2015. Prosedur Pelabelan Produk Pangan Ditinjau Menurut Peraturan Pemerintah Nomor 69 Tahun 1999. Riau: Universitas Islam Negeri Sultan Syarif Kasim Riau. Retrieved from http://repository.uinsuska.ac.id/7112/

Noviani, B. F. 2019. Meningkatkan Kompetensi Guru Kelas Dalam Penyusunan Rpp Melalui Pendampingan Berbasis Kkg Di Sd Negeri 34 Mataram Semester Dua Tahun Pelajaran 2017/2018. Media Bina Ilmiah. Retrieved from https://www.researchgate.net/publi cation/332728799

Suprapto, R., \& Azizi, Z. W. 2020. Pengaruh Kemasan, Label Halal, Label Izin P-IRT Terhadap 
Keputusan Pembelian Konsumen

UMKM Kerupuk Ikan. Jurnal

REKOMEN (Riset Ekonomi

Manajemen). Retrieved from

https://jurnal.untidar.ac.id/index.ph

$\mathrm{p} /$ rekomen/article/view/1984

Undang-undang Nomor 20 Tahun 2016

tentang Merek.

http://www.hki.co.id/hki.html.

https://www.easybiz.id/ini-alasan-

pendaftaran-merek-penting-bagi-

umkm-untuk-mengembangkan-

bisnis/.

https://www.kajianpustaka.com/2018/03/p

engertian-fungsi-jenis-dan-

ketentuan-label.html. 